\title{
Flexural behaviour of steel fibre reinforced concrete beams made with copper slag as partial fine aggregate replacement
}

\author{
$D A S$ Mohd Areef ${ }^{1}, P$ Srinivasa $\mathrm{Rao}^{2}, V$ Srinivasa Reddy ${ }^{3}$, and $D$ Mohd Azeem Zubair ${ }^{4}$ \\ ${ }^{1}$ Research Scholar of Civil Engineering, JNTU Ananthapur, Andhra Pradesh, India. Email: arinfratechengr@gmail.com \\ ${ }^{2}$ Professor, Civil Engineering Department, JNTUH, Hyderabad, Telangana, India. Email: srinivasa.pt@gmail.com \\ ${ }^{3}$ Professor, Civil Engineering Department, GRIET, Hyderabad, Telangana, India. Email:vempada@gmail.com \\ ${ }^{4} \mathrm{M} / \mathrm{S}$ DAS Nirman (P) Limited, Hyderabad, Telangana, India.
}

\begin{abstract}
Lately, development of concrete using industrial byproducts has garnered major significance in the construction industry in order to overcome problems associated with depleted natural resources. As, river sand is costly and also large scale exhaustion of these sources generates environmental harms, a substitute or replacement product for concrete industry is very indispensable. In such a situation, the copper slag can be proposed as an alternative to the river sand, which is an industrial by-product obtained from the manufacturing of copper. The present investigation assesses the incorporation of copper slag in concrete (CSC). In this paper, experimental investigations are carried to understand the flexural characteristics such as such as first crack, ultimate load carrying capacity, maximum crack width and deflection at service load and at centre of steel fibred copper slag mixed under-reinforced concrete beams. Results showed that the compressive strength of concrete decreases as copper slag content increases beyond $40 \%$. The reduction in compressive strength beyond $40 \%$ replacement of river sand due to the increase in free water content in concrete mixes due to the low absorption properties of copper slag which can cause excessive bleeding at higher copper slag content. The load-deflection behaviour of under-reinforced, normal and copper slag concrete beams is witnessed to be alike apart from the increased values of ultimate failure loads and ultimate deflections at failure in steel fibred copper slag concrete beams.
\end{abstract}

\section{Introduction}

For every one ton of copper production, about 2.2 tons of copper slag is generated as by-product [1]. Around 25 million tons of copper slag was produced in the copper plants which has properties to be used as supplementary cementitious material and also as replacement for river sand as fine aggregate. Copper slag has good resistance to abrasion and less impurities. Copper slag also exhibits pozzolanic properties since it contains low $\mathrm{CaO}$ [6]. To demonstrate the copper slag as sustainable and eco-friendly material which can be used in construction industry [3]. The objective of the current study is to determine the flexural characteristics such as such as first crack, ultimate load carrying capacity, maximum crack width and deflection at service load and at centre of steel fibred copper slag mixed under-reinforced concrete beams. Various researchers have used copper slag as river sand replacement for certain percentage but limited studies are made to assess its mechanical and durability properties.

\section{Material properties and Investigations}

To acquire precise experimental statistics which supports to comprehend the flexural performance and importance of consumption of copper slag as limited replacement of natural sand as fine aggregate, the investigational agenda was engaged up [4].

Cement of grade 53 used for the study was tested its properties conforming to IS-4031 1988. It has specific gravity of 3.1 and other physical properties are within the limits suggested by the IS Code [5].

Locally available sand is used as fine aggregate which passes through $4.75 \mathrm{~mm}$ and retained on $0.075 \mathrm{~mm}$ sieves [6]. The fine aggregate is conforming to Zone II as per IS 383-1970. However the properties of fine aggregate is tested as per IS 2386-1963 and was found that Specific gravity as 
2.62, Bulk density (loose state) as $1607 \mathrm{~kg} / \mathrm{m}^{3}$ and Bulk density(compacted state) as $1703 \mathrm{~kg} / \mathrm{m}^{3}$.

Coarse aggregate used is crushed granite angular aggregate passing through $20 \mathrm{~mm}$ and retained on $4.75 \mathrm{~mm}$ sieve. The coarse aggregate used is conforms to IS 383-

Copper slag used for the study was bought from Sterlite industries (India) 1td, Tuticorin, Tamil Nadu, India. Its specific gravity lies between 3.5 to 3.8 , the bulk density of copper slag varies between 1.9 to $2.15 \mathrm{~kg} / \mathrm{m}^{3}$ which is almost similar to the bulk density of conventional fine aggregate. Copper slag has high composition of oxides of iron and silica.

Various dosages of, $0.5 \%, 1 \%, 1.5 \%$ and $2 \%$ by volume of concrete, crimped steel fibers of aspect ratio 70 (length $35 \mathrm{~mm}$ ) are used [7]. One sample of M30 grade steel fibred concrete beams made with natural sand and another sample of M30 grade steel fibred concrete beams made with optimum amount of copper slag as sand replacement were casted.

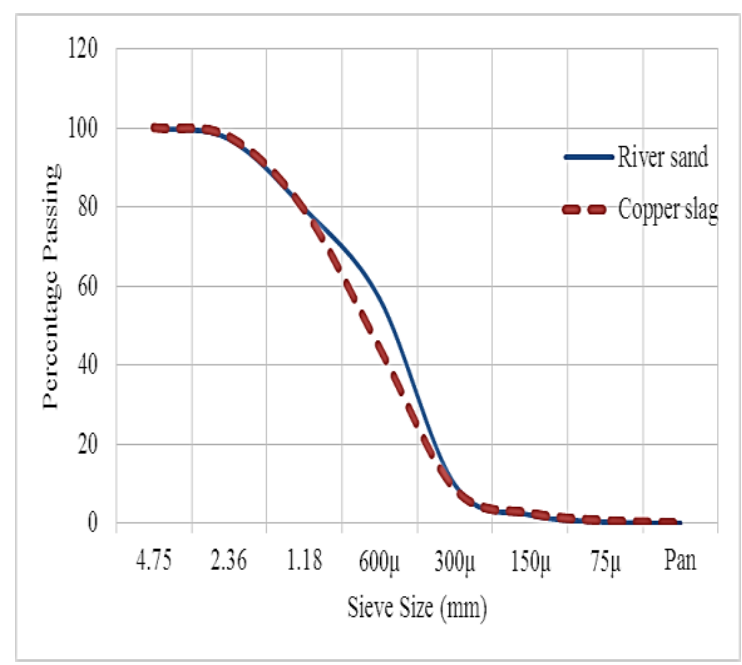

Fig. 1. Particle size distribution curve of River sand and Copper Slag

Table 1. Chemical Composition of Copper Slag

\begin{tabular}{|c|c|c|}
\hline S.No & Compound & Percentage \\
\hline & $\mathrm{Fe}_{2} \mathrm{O}_{3}$ & $55-60 \%$ \\
\hline
\end{tabular}

1970 and is tested as per IS 2386-1963 for its physical properties. Its specific gravity 2.63, Bulk density (loose state) as $1410 \mathrm{~kg} / \mathrm{m}^{3}$ and Bulk density (compacted state) as $1546 \mathrm{~kg} / \mathrm{m}^{3}$.

\begin{tabular}{|c|c|c|}
\hline & $\mathrm{SiO}_{2}$ & $27-33 \%$ \\
\hline & $\mathrm{CaO}$ & $1-3.5 \%$ \\
\hline & $\mathrm{Al}_{2} \mathrm{O}_{3}$ & $3 \%$ \\
\hline & $\mathrm{Cu}$ & $<1 \%$ \\
\hline & Free moisture & $1-2 \%$ \\
\hline
\end{tabular}

The M30 concrete mix proportions were designed as per IS 10262-2009. Proportions of concrete mix ingredients per cubic meter are presented in table 2.

Table 2. Proportions of M30 Concrete

\begin{tabular}{|c|c|c|}
\hline S.No & Material & Quantity $\left(\mathrm{kg} / \mathrm{m}^{3}\right)$ \\
\hline 1. & Cement & 350 \\
\hline 2. & Fine aggregate & 704 \\
\hline 3. & Coarse aggregate & 1164 \\
\hline 4. & & \\
\hline 5. & Water & 175 \\
\hline 6. & Water cement ratio & 0.5 \\
\hline \multicolumn{3}{|c|}{$\begin{array}{l}\text { Cement: Fine Aggregate: Coarse Aggregate: w/c ratio } \\
=1: 2.01: 3.33: 0.50\end{array}$} \\
\hline
\end{tabular}

These basic M30 grade concrete mix proportions were further altered by using copper slag as a partial replacement of river sand and adding crimped steel fibres to study the effect of copper slag in steel fibre reinforced concrete. The incremental percentage replacement of river sand with copper slag by weight ranges from $0 \%$ to $50 \%$ and dosage of crimped steel fibre used are $0.5 \%, 1.0 \%, 1.5 \%$ and $2 \%$ by total volume of concrete. The mix proportions calculated for M30 grade Conventional Concrete (CC), Copper slag based concrete without steel fibre (CSC) and Copper slag based steel fibre reinforced concrete (CS-SFRC) are tabulated in tables 3 and 4 . Table 5 shows the slump values of CSC, SFRC and CS-SFRC mixes.

Table 3. Mix quantities of M30 Grade Copper Slag Concrete (CSC)

\begin{tabular}{|c|c|c|c|c|c|c|}
\hline \multirow{3}{*}{ Grade } & Mix & $\begin{array}{c}\text { Cement } \\
\left(\mathrm{kg} / \mathrm{m}^{3}\right)\end{array}$ & $\begin{array}{c}\text { Copper Slag } \\
\left(\mathrm{kg} / \mathrm{m}^{3}\right)\end{array}$ & $\begin{array}{c}\text { Water } \\
(\text { Litres })\end{array}$ & $\begin{array}{c}\text { Fine Aggregate } \\
\left(\mathrm{kg} / \mathrm{m}^{3}\right)\end{array}$ & $\begin{array}{c}\text { Coarse } \\
\text { Aggregate } \\
\left(\mathrm{kg} / \mathrm{m}^{3}\right)\end{array}$ \\
\hline \multirow{6}{*}{ M30 } & $C S(0)$ & 350 & 0 & 175 & 703.6 & 1164 \\
\cline { 2 - 7 } & $C S(10)$ & 350 & 70.36 & 175 & 633.24 & 1164 \\
\cline { 2 - 7 } & $C S(20)$ & 350 & 140.72 & 175 & 562.88 & 1164 \\
\cline { 2 - 7 } & $C S(30)$ & 350 & 211.08 & 175 & 492.52 & 1164 \\
\cline { 2 - 7 } & $C S(40)$ & 350 & 281.44 & 175 & 422.16 & 1164 \\
\hline
\end{tabular}

* In designation CS(N), CS means copper slag replaced concrete mix and value ' $\mathrm{N}$ ' indicates the percentage replacement of river sand by copper slag. 
Table 4. Mix quantities of M30 Grade Copper slag based Steel Fibre Reinforced Concrete

\begin{tabular}{|c|c|c|c|c|c|c|c|}
\hline \multirow{2}{*}{ Grade } & \multirow{2}{*}{ Mix } & \multirow{2}{*}{$\begin{array}{l}\text { Cement } \\
\left(\mathrm{kg} / \mathrm{m}^{3}\right)\end{array}$} & \multirow{2}{*}{$\begin{array}{c}\text { Water } \\
\text { (Litres) }\end{array}$} & \multicolumn{2}{|c|}{ Fine Aggregate $\left(\mathrm{kg} / \mathrm{m}^{3}\right)$} & \multirow{2}{*}{$\begin{array}{c}\text { Coarse Aggregate } \\
\left(\mathrm{kg} / \mathrm{m}^{3}\right)\end{array}$} & \multirow{2}{*}{$\begin{array}{c}\text { Steel Fibre } \\
\left(\mathrm{kg} / \mathrm{m}^{3}\right)\end{array}$} \\
\hline & & & & River Sand & Copper slag & & \\
\hline \multirow{10}{*}{ M30 } & $C_{0} S_{0}$ & 350 & 175 & 703.60 & 0 & 1164 & 0 \\
\hline & $C_{0} S_{0.5}$ & 350 & 175 & 703.60 & 0 & 1164 & 39.25 \\
\hline & $C_{0} S_{I}$ & 350 & 175 & 703.60 & 0 & 1164 & 78.50 \\
\hline & $C_{0} S_{1.5}$ & 350 & 175 & 703.60 & 0 & 1164 & 117.75 \\
\hline & $C_{0} S_{2}$ & 350 & 175 & 703.60 & 0 & 1164 & 157.00 \\
\hline & $C_{40} S_{0}$ & 350 & 175 & 281.44 & 422.16 & 1164 & 0 \\
\hline & $C_{40} S_{0.5}$ & 350 & 175 & 281.44 & 422.16 & 1164 & 39.25 \\
\hline & $C_{40} S_{1}$ & 350 & 175 & 281.44 & 422.16 & 1164 & 78.50 \\
\hline & $C_{40} S_{1.5}$ & 350 & 175 & 281.44 & 422.16 & 1164 & 117.75 \\
\hline & $C_{40} S_{2}$ & 350 & 175 & 281.44 & 422.16 & 1164 & 157.00 \\
\hline
\end{tabular}

* In designation $\mathrm{C}_{\mathrm{x}} \mathrm{S}_{\mathrm{y}}$, ' $\mathrm{C}$ ' means copper slag, ' $\mathrm{x}$ ' means percentage of river sand replacement with copper slag, $\mathrm{S}$ means Steel fibre and ' $y$ ' indicates dosage of steel fibre by volume of concrete.

Concrete cubes of size $150 \mathrm{~mm}$ and prisms of size $100 \mathrm{~mm} \times 100 \mathrm{~mm} \times 500 \mathrm{~mm}$ were casted with various proportions of copper slag ranging from $0 \%$ to $50 \%$ replacement for river sand and with various dosages of crimped steel fibre ranging from $0.5 \%$ to $2 \%$ by volume of concrete to test for compressive and flexural strength of copper slag mixed steel fibre reinforced concrete.

Conventional and copper slag + steel fibre mixed under-reinforced concrete beams of size $1200 * 100 * 150 \mathrm{~mm}$ with a reinforcement of $4-10 \mathrm{~mm} \phi$ HYSD bars and stirrups of $8 \mathrm{~mm} \phi$ at a spacing of $200 \mathrm{~mm} \mathrm{c} / \mathrm{c}$ were casted and tested for flexural characteristics such as first crack, ultimate load carrying capacity, maximum crack width and deflection at service load and at centre are evaluated under two point loading test as per IS: 9399 - 1979 using universal testing machine of capacity $1000 \mathrm{kN}$ and presented in table $7-9$.

Table 5. Slump values of M30 Grade CC, CSC and CS-SFRC

\begin{tabular}{|c|c|c|}
\hline S.No & Mix Designation & Slump in mm \\
\hline 1 & $C S(0)$ & 74 \\
\hline 2 & $C S(10)$ & 75 \\
\hline 3 & $C S(20)$ & 77 \\
\hline 4 & $C S(30)$ & 79 \\
\hline 5 & $C S(40)$ & 81 \\
\hline 6 & $C S(50)$ & 82 \\
\hline 7 & $C_{0} S_{0}$ & 74 \\
\hline 8 & $C S_{0} S F_{0.5}$ & 62 \\
\hline 9 & $C S_{0} S F_{1}$ & 46 \\
\hline 10 & $C S_{0} S F_{1.5}$ & 38 \\
\hline 11 & $C S_{0} S F_{2}$ & 24 \\
\hline 12 & $C S_{40} S F_{0}$ & 81 \\
\hline 13 & $C S_{40} S F_{0.5}$ & 66 \\
\hline 14 & $C S_{40} S F_{1}$ & 45 \\
\hline 15 & $C S_{40} S F_{1.5}$ & 40 \\
\hline 16 & $C S_{0} S F_{2}$ & 27 \\
\hline
\end{tabular}

Table 6. Compressive strengths of CSC and CS-SFRC mixes

\begin{tabular}{|c|c|c|}
\hline Mix Designation & $\begin{array}{c}\text { Compressive } \\
\text { Strength (MPa) }\end{array}$ & $\begin{array}{c}\text { Flexural } \\
\text { Strength } \\
\text { (MPa) }\end{array}$ \\
\hline$C S(0)$ & 38.90 & 3.32 \\
\hline$C S(10)$ & 39.11 & 3.44 \\
\hline$C S(20)$ & 42.33 & 3.48 \\
\hline$C S(30)$ & 43.56 & 3.51 \\
\hline$C S(40)$ & 45.81 & 3.55 \\
\hline$C S(50)$ & 34.78 & 2.45 \\
\hline$C S_{0} S F_{0}$ & 38.90 & 3.32 \\
\hline$C S_{0} S F_{0.5}$ & 38.99 & 3.65 \\
\hline$C S_{0} S F_{1}$ & 39.11 & 3.99 \\
\hline$C S_{0} S F_{1.5}$ & 40.34 & 4.56 \\
\hline$C S_{0} S F_{2}$ & 42.19 & 4.78 \\
\hline$C S_{40} S F_{0}$ & 44.62 & 3.38 \\
\hline$C S_{40} S F_{0.5}$ & 46.10 & 3.80 \\
\hline$C S_{40} S F_{1}$ & 48.13 & 4.01 \\
\hline$C S_{40} S F_{1.5}$ & 49.22 & 4.88 \\
\hline$C S_{40} S F_{2}$ & 49.87 & 4.96 \\
\hline & &
\end{tabular}


Table 7. Load deflections of M30 grade steel fibred conventional reinforced concrete

\begin{tabular}{|l|c|c|c|c|c|c|c|c|c|c|}
\hline \multirow{2}{*}{ S.No } & \multicolumn{2}{|c|}{$\begin{array}{c}0 \% \\
\text { steel fibres }\end{array}$} & \multicolumn{2}{c|}{$\begin{array}{c}0.5 \% \\
\text { steel fibres }\end{array}$} & \multicolumn{2}{c|}{$\begin{array}{c}1 \% \\
\text { steel fibres }\end{array}$} & \multicolumn{2}{c|}{$\begin{array}{c}1.5 \% \\
\text { steel fibres }\end{array}$} & \multicolumn{2}{c|}{$\begin{array}{c}2 \% \\
\text { steel fibres }\end{array}$} \\
\cline { 2 - 12 } & $\begin{array}{c}\text { Load } \\
(\mathrm{kN})\end{array}$ & $\begin{array}{c}\text { Deflection } \\
(\mathrm{mm})\end{array}$ & $\begin{array}{c}\text { Load } \\
(\mathrm{kN})\end{array}$ & $\begin{array}{c}\text { Deflection } \\
(\mathrm{mm})\end{array}$ & $\begin{array}{c}\text { Load } \\
(\mathrm{kN})\end{array}$ & $\begin{array}{c}\text { Deflection } \\
(\mathrm{mm})\end{array}$ & $\begin{array}{c}\text { Load } \\
(\mathrm{kN})\end{array}$ & $\begin{array}{c}\text { Deflection } \\
(\mathrm{mm})\end{array}$ & $\begin{array}{c}\text { Load } \\
(\mathrm{kN})\end{array}$ & $\begin{array}{c}\text { Deflection } \\
(\mathrm{mm})\end{array}$ \\
\hline 1. & 5 & 0.37 & 5 & 0.14 & 5 & 0.19 & 5 & 0.11 & & 0.15 \\
\hline 2. & 10 & 0.42 & 10 & 0.29 & 10 & 0.32 & 10 & 0.31 & 10 & 0.20 \\
\hline 3. & 15 & 0.89 & 15 & 0.57 & 15 & 0.59 & 15 & 0.49 & 15 & 0.39 \\
\hline 4. & 20 & 1.29 & 20 & 1.03 & 20 & 1.04 & 20 & 0.87 & 20 & 0.62 \\
\hline 5. & 25 & 1.82 & 25 & 1.79 & 25 & 1.63 & 25 & 1.35 & 25 & 1.27 \\
\hline 6. & 30 & 2.22 & 30 & 2.54 & 30 & 2.22 & 30 & 1.87 & 30 & 1.85 \\
\hline 7. & 35 & 2.65 & 35 & 3.30 & 35 & 2.88 & 35 & 2.60 & 35 & 2.41 \\
\hline 8. & 40 & 3.14 & 40 & 4.03 & 40 & 3.69 & 40 & 3.28 & 40 & 3.04 \\
\hline 9. & 45 & 5.28 & 45 & 4.79 & 45 & 4.93 & 45 & 3.89 & 45 & 3.59 \\
\hline 10. & $\mathbf{5 4}$ & $\mathbf{6 . 8 0}$ & 50 & 5.50 & 50 & 5.40 & 50 & 4.90 & 50 & 4.19 \\
\hline 11. & & & 55 & 6.78 & 55 & 6.87 & 55 & 7.95 & 55 & 5.90 \\
\hline 12. & & & $\mathbf{6 1}$ & $\mathbf{7 . 9 4}$ & 60 & 8.22 & 60 & 8.13 & 60 & 7.82 \\
\hline 13. & & & & 65 & 9.43 & 65 & 9.44 & 65 & 9.76 \\
\hline 14. & & & & & $\mathbf{6 8}$ & $\mathbf{1 0 . 2 6}$ & 70 & 10.57 & 70 & 10.56 \\
\hline 15. & & & & & & & $\mathbf{7 4}$ & $\mathbf{1 1 . 0 9}$ & 75 & 12.40 \\
\hline 16. & & & & & & & & & $\mathbf{8 0}$ & $\mathbf{1 3 . 6 7}$ \\
\hline
\end{tabular}

Table 8. Load deflections of M30 grade steel fibred copper slag reinforced concrete beams

\begin{tabular}{|l|c|c|c|c|c|c|c|c|c|c|}
\hline \multirow{2}{*}{ S.No } & \multicolumn{2}{|c|}{$\begin{array}{c}0 \% \\
\text { steel fibres }\end{array}$} & \multicolumn{2}{c|}{$\begin{array}{c}0.5 \% \\
\text { steel fibres }\end{array}$} & \multicolumn{2}{c|}{$\begin{array}{c}1 \% \\
\text { steel fibres }\end{array}$} & \multicolumn{2}{c|}{$\begin{array}{c}1.5 \% \\
\text { steel fibres }\end{array}$} & \multicolumn{2}{c|}{$\begin{array}{c}2 \% \\
\text { steel fibres }\end{array}$} \\
\cline { 2 - 12 } & $\begin{array}{c}\text { Load } \\
(\mathrm{kN})\end{array}$ & $\begin{array}{c}\text { Deflection } \\
(\mathrm{mm})\end{array}$ & $\begin{array}{c}\text { Load } \\
(\mathrm{kN})\end{array}$ & $\begin{array}{c}\text { Deflection } \\
(\mathrm{mm})\end{array}$ & $\begin{array}{c}\text { Load } \\
(\mathrm{kN})\end{array}$ & $\begin{array}{c}\text { Deflection } \\
(\mathrm{mm})\end{array}$ & $\begin{array}{c}\text { Load } \\
(\mathrm{kN})\end{array}$ & $\begin{array}{c}\text { Deflection } \\
(\mathrm{mm})\end{array}$ & $\begin{array}{c}\text { Load } \\
(\mathrm{kN})\end{array}$ & $\begin{array}{c}\text { Deflection } \\
(\mathrm{mm})\end{array}$ \\
\hline 1. & 5 & 0.14 & 5 & 0.10 & 5 & 0.09 & 5 & 0.09 & 5 & 0.14 \\
\hline 2. & 10 & 0.20 & 10 & 0.31 & 10 & 0.30 & 10 & 0.19 & 10 & 0.56 \\
\hline 3. & 15 & 0.39 & 15 & 0.64 & 15 & 0.72 & 15 & 0.49 & 15 & 0.81 \\
\hline 4. & 20 & 0.78 & 20 & 0.95 & 20 & 0.96 & 20 & 0.95 & 20 & 0.88 \\
\hline 5. & 25 & 1.24 & 25 & 1.53 & 25 & 1.54 & 25 & 1.38 & 25 & 0.97 \\
\hline 6. & 30 & 1.86 & 30 & 2.19 & 30 & 2.09 & 30 & 1.89 & 30 & 1.44 \\
\hline 7. & 35 & 2.89 & 35 & 2.84 & 35 & 2.70 & 35 & 2.49 & 35 & 1.95 \\
\hline 8. & 40 & 3.69 & 40 & 3.49 & 40 & 3.29 & 40 & 2.96 & 40 & 2.39 \\
\hline 9. & 45 & 4.68 & 45 & 5.57 & 45 & 3.90 & 45 & 3.47 & 45 & 2.90 \\
\hline 10. & 50 & 5.14 & 50 & 6.04 & 50 & 5.59 & 50 & 4.08 & 50 & 3.40 \\
\hline 11. & 55 & 6.03 & 55 & 6.99 & 55 & 6.46 & 55 & 6.14 & 55 & 4.38 \\
\hline 12. & $\mathbf{5 7}$ & $\mathbf{6 . 9 2}$ & 60 & 7.41 & 60 & 7.67 & 60 & 7.34 & 60 & 7.12 \\
\hline 13. & & & 65 & 7.93 & 65 & 8.24 & 65 & 8.57 & 65 & 8.90 \\
\hline 14. & & & $\mathbf{6 6}$ & $\mathbf{8 . 2 3}$ & 70 & 9.77 & 70 & 9.29 & 70 & 9.81 \\
\hline 15. & & & & & $\mathbf{7 3}$ & $\mathbf{1 0 . 8 8}$ & 75 & 10.52 & 75 & 11.09 \\
\hline 16. & & & & & & & $\mathbf{7 8}$ & $\mathbf{1 1 . 4 5}$ & 80 & 12.68 \\
\hline 17. & & & & & & & & & $\mathbf{8 4}$ & $\mathbf{1 4 . 0 1}$ \\
\hline
\end{tabular}


Table 9. Flexural Characteristics of steel fibred and copper slag + steel fibre M30 grade concrete beams

\begin{tabular}{|c|c|c|c|c|c|c|c|c|}
\hline $\begin{array}{c}\text { Percentage of } \\
\text { Steel Fibers by } \\
\text { volume of } \\
\text { concrete }\end{array}$ & $\begin{array}{c}\text { M30 Grade Reference Concrete } \\
\begin{array}{c}\text { First Crack } \\
\text { occurrence } \\
(\mathrm{kN})\end{array}\end{array}$ & $\begin{array}{c}\text { Load @ } \\
\text { Failure } \\
(\mathrm{kN})\end{array}$ & $\begin{array}{c}\text { Mid-deflection } \\
(\mathrm{mm})\end{array}$ & $\begin{array}{c}\text { Width of } \\
\text { Crack @ } \\
\text { failure } \\
(\mathrm{mm})\end{array}$ & $\begin{array}{c}\text { Moad @ } \\
\text { First Crack } \\
\text { occurrence } \\
(\mathrm{kN})\end{array}$ & $\begin{array}{c}\text { Load @ } \\
\text { Failure } \\
(\mathrm{kN})\end{array}$ & $\begin{array}{c}\text { Mid-deflection } \\
(\mathrm{mm})\end{array}$ & $\begin{array}{c}\text { Width of Crack } \\
\text { fine failure } \\
(\mathrm{mm})\end{array}$ \\
\hline $0 \%$ & 23 & 54 & 6.80 & 0.99 & 31 & 57 & 6.92 & 0.99 \\
\hline $0.5 \%$ & 31 & 61 & 7.94 & 0.91 & 32 & 66 & 8.23 & 0.91 \\
\hline $1.0 \%$ & 36 & 68 & 10.26 & 0.81 & 38 & 73 & 10.88 & 0.80 \\
\hline $1.5 \%$ & 43 & 74 & 11.09 & 0.81 & 47 & 78 & 11.45 & 0.76 \\
\hline $2 \%$ & 49 & 80 & 13.69 & 0.80 & 61 & 84 & 14.01 & 0.76 \\
\hline
\end{tabular}

\section{Discussions}

Table 1 displays the chemical properties of copper slag. Figure 1 shows the particle size distribution of river sand and copper slag which conforms to Zone II as per IS Code. The optimum percentage of copper slag as partial replacement of sand from compressive strength perspective was chosen as $40 \%$. The fresh concrete made with copper slag gives a stable non-segregating concrete reducing the possibility of blocking during pumping. Bleeding and surface integrity can be enriched by the addition of steel fibres and homogeneity of concrete reducing the probability of cracks occurring. The flexural characteristics of concrete is improved by addition of fibers which also controls the width of the cracks. Load at which first crack appear is recorded so that service load criteria can be checked. For complete failure, load at failure is studied along with the width of crack. From Load-deflection test results it can be understood that copper slag replaced RCC and SFRC beams are stiffer than the conventional RCC beams and SFRC beams. The yield and ultimate load taken by copper slag replaced SFRC beams are higher than the conventional RCC and SFRC beam elements. Even though the deflection of copper slag admixed RCC and SFRC beams was higher than RCC and SFRC beams, the load carrying capacity of copper slag admixed RCC and SFRC beams are greater than normal RCC and SFRC elements. This shows the ductile behavior of RCC beams incorporating copper slag as partial replacement of sand is higher than the normal RCC and SFRC Beams. Horizontal cracks were not noticed at the reinforcement level showing that there was no bond failure.

\section{Conclusions}

Based on the experimental investigations and test results the following conclusions are documented as below-

1. Due to high partice packing density in concrete made with $40 \%$ replacement of river sand with copper slag. Micro cracks are prevented due to enahnced fatigue and stress dissipation capacity.

2. Concrete's, made with $40 \%$ copper slag and rest river sand, microsctructure is so dense that the concrete becomes nearly impermeable with reduced pore sizes, pore diameters, pore volume and total porosity of concrete

3. The load carrying capacity of beams was found to be increasing with the usage of optiumum amount of copper slag in concrete.

4. The deflections at centre at failure in copper slag concrete beams were more than that of conventional beams. This shows improvement in ductility of copper slag concrete beams.

5. The load-deflection behaviour of under-reinforced, normal and copper slag concrete beams is witnessed to be alike apart from the increased values of ultimate failoure loads and loads at first crack in copper slag concrete beams.

6. Steel fibred copper slag concrete beams regulate the beginning of micro-cracks improving the ductility of concrete specimens under flexure.

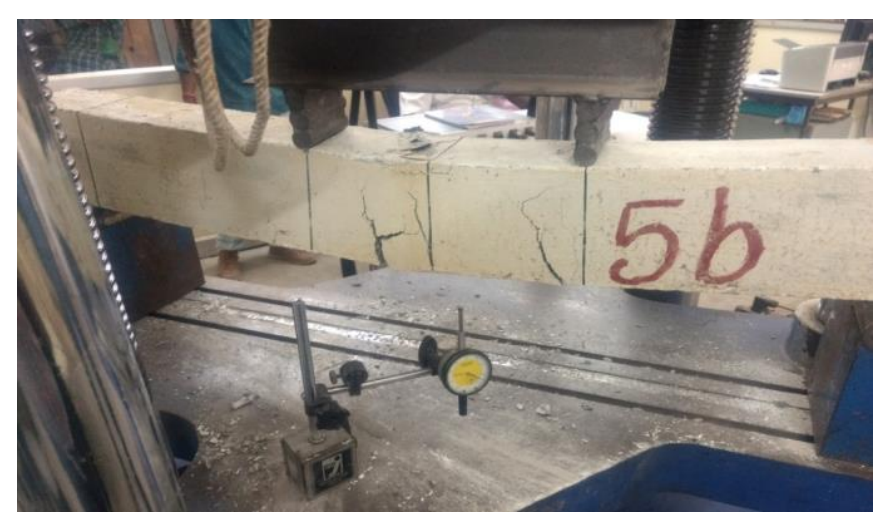

Fig 2. Flexural testing of beams 

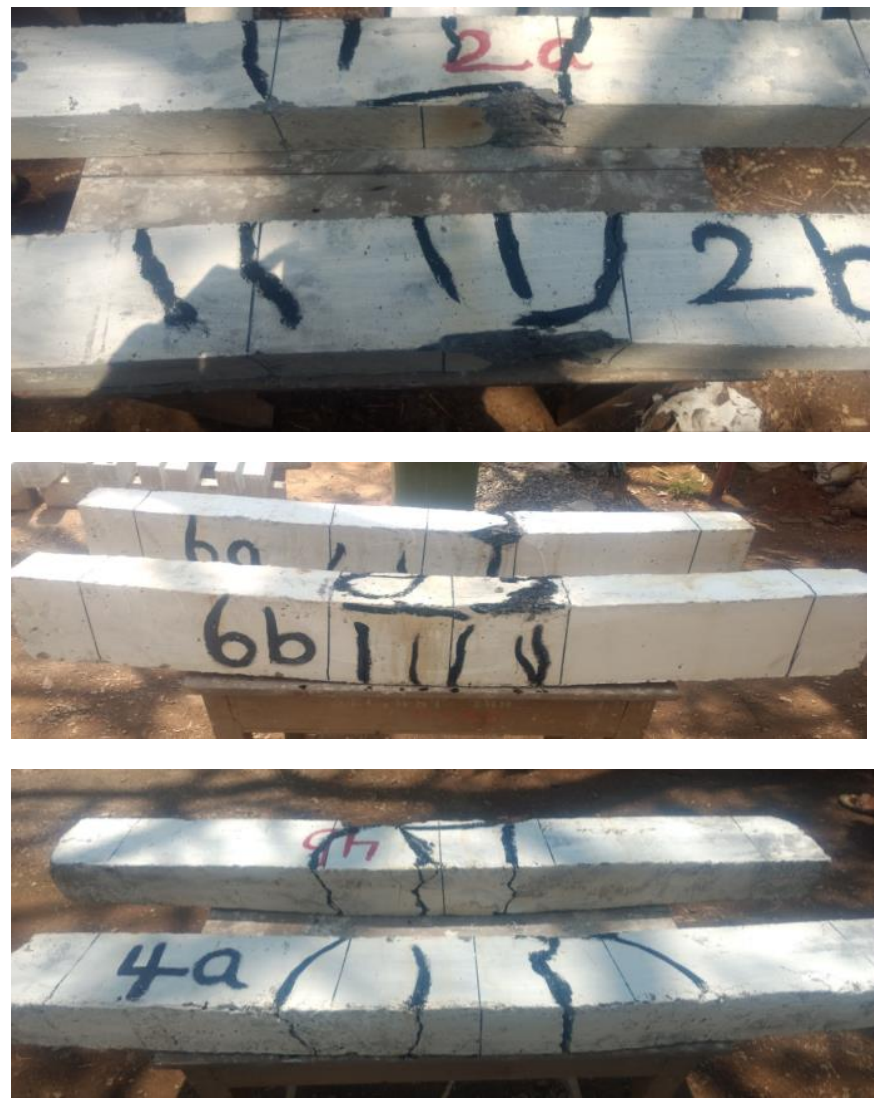

Fig3. Failure and Crack Pattern of M30 Beam

\section{References}

1. R. Agarwal., A.K. Singh, and D Singhal,., Effect of fibre reinforcing index on compressive and bond strength of steel fibre reinforced concrete, Journal of the institutions of engineers (India), Vol. 77, pp. 37-40, (1996).

2. K Al-Jabri,, K Salem Al-Oraimi, Abdullah Al-Saidy and Makoto Hisada, Copper slag as sand replacement for high performance concrete, Cement \& Concrete Composites, Vol. 31, pp. 483-488, (2009).

3. K.S Al-Jabri,, H Abdullah, Al-Saidy and Ramzi Taha, Effect of copper slag as a fine aggregate on the properties of cement mortars and concrete, Construction and Building Materials, Vol. 25, pp. 933938, (2011).

4. K.S Al-Jabri, Makoto Hisada, H.A. Abdulla, and S.K. Al-Oraini, Performance of high strength concrete made with copper slag as a fine aggregate, Construction and building materials, Vol. 23, pp. 2132-2140, (2009).

5. A.M. Arino, and B Mobasher, Effect of copper slag on the strength, and toughness of cementitious mixtures, ACI Materials Journal, Vol. 96, No. 1, pp. 68-75, (1999).

6. Ayano Toshiki, Kuramoto Osamu, and Sakata Kenji, Concrete with copper slag fine aggregate, Society of Materials Science, Vol. 49, pp. 1097-1102, (2000).
7. Binaya Patnaik, T Seshadri Sekhar,. and Srinivasa Rao, An Experimental Investigation on Optimum Usage of Concrete Slag as Fine Aggregate in Copper Slag Admixed Concrete, International Journal of Current Engineering and Technology, Vol. 4, No. 5, (2014).

8. Binaya Patnaik, T Seshadri Sekhar, and Srinivasa Rao, Relationship between the Optimum Usage Of Copper Slag as Fine Aggregate and Compressive Strength in Copper Slag Admixed Concrete, i-manager's Journal on Civil Engineering, Vol. 4, No. 2, (2014).

9. Bipra Gorai, R.K Jana, and Prem chand, Characteristics and Utilization of copper slag - a review, Resources, Conservation and Recycling, Science Direct, Vol. 39, No. 4, pp. 299- 313, (2003).

10. D. Brindha, and $\mathrm{S}$ Nagan, Utilization of copper slag as a partial replacement of fine aggregate, International Journal of Earth Sciences and Engineering, Vol. 3, No. 4, pp. 579-585, (2010).

11. Byung Sik Chun, Du Hee Park, and Hun Chul Jung "A Study on the Application of Copper Slag as a Sand Substitute of Sand Compaction Pile", proceedings of 15th international off shore and polar Engineering conference, (2005), pp.1661-1665

12. B Mobasher, $r$ Devaguptapu, and A M Arino, Effect of copper slag on the hydration of blended cementitious mixtures, Proceedings of the ASCE materials engineering conference, pp. 1677-1686, (1996).

13. T.Srinivas and N.V.Ramana Rao, Studies on the Behaviour of Sulphate Attack Resistance of Low Calcium Fly Ash and Slag Based Geopolymer Concrete, International Journal of Civil Engineering and Technology (IJCIET), Volume 10, Issue 02, pp. 510-518 (2019)

14. N Sateesh,, P Sampath Rao, D V Ravishanker, K Satyanarayana, Effect of Moisture on GFRP Composite Materials, Materials Today: Proceedings, 2 (4-5), pp. 2902-2908 (2015). 